OPEN ACCESS

Edited by:

Anssi Peräkylä,

University of Helsinki, Finland

Reviewed by:

Michael Bamberg,

Clark University, United States

Eugénia Ribeiro,

University of Minho, Portugal

Elina Weiste,

Finnish Institute of Occupational

Health, Finland

*Correspondence:

Arnulf Deppermann

deppermann@ids-mannheim.de

Specialty section:

This article was submitted to

Psychology for Clinical Settings,

a section of the journal

Frontiers in Psychology

Received: 14 June 2020 Accepted: 10 September 2020

Published: 26 October 2020

Citation:

Deppermann A, Scheidt CE and Stukenbrock A (2020) Positioning Shifts From Told Self to Performative Self in Psychotherapy.

Front. Psychol. 11:572436. doi: 10.3389/fpsyg.2020.572436

\section{Positioning Shifts From Told Self to Performative Self in Psychotherapy}

\author{
Arnulf Deppermann ${ }^{1,2 *}$, Carl Eduard Scheidt ${ }^{3}$ and Anja Stukenbrock ${ }^{4}$ \\ ${ }^{1}$ Pragmatics Department, Leibniz-Institute for the German Language, Mannheim, Germany, ${ }^{2}$ Department of Finnish, \\ Finno-Ugrian and Scandinavian Studies, University of Helsinki, Helsinki, Finland, ${ }^{3}$ Department of Psychosomatic Medicine \\ and Psychotherapy, Faculty of Medicine, Albert-Ludwigs-Universität Freiburg, Freiburg, Germany, ${ }^{4}$ Faculté des Lettres, \\ Section d'allemand, Université de Lausanne, Lausanne, Switzerland
}

According to Positioning Theory, participants in narrative interaction can position themselves on a representational level concerning the autobiographical, told self, and a performative level concerning the interactive and emotional self of the tellers. The performative self is usually much harder to pin down, because it is a non-propositional, enacted self. In contrast to everyday interaction, psychotherapists regularly topicalize the performative self explicitly. In our paper, we study how therapists respond to clients' narratives by interpretations of the client's conduct, shifting from the autobiographical identity of the told self, which is the focus of the client's story, to the present performative self of the client. Drawing on video recordings from three psychodynamic therapies (tiefenpsychologisch fundierte Psychotherapie) with 25 sessions each, we will analyze in detail five extracts of therapists' shifts from the representational to the performative self. We highlight four findings:

- Whereas, clients' narratives often serve to support identity claims in terms of personal psychological and moral characteristics, therapists rather tend to focus on clients' feelings, motives, current behavior, and ways of interacting.

- In response to clients' stories, therapists first show empathy and confirm clients' accounts, before shifting to clients' performative self.

- Therapists ground the shift to clients' performative self by references to clients' observable behavior.

- Therapists do not simply expect affiliation with their views on clients' performative self. Rather, they use such shifts to promote the clients' self-exploration. Yet, if clients resist to explore their selves in more detail, therapists more explicitly ascribe motives and feelings that clients do not seem to be aware of. The shift in positioning levels thus seems to have a preparatory function for engendering therapeutic insights.

Keywords: psychoanalysis, conversation analysis, positioning, interpretation, psychotherapy, social interaction, self 


\section{INTRODUCTION}

The self is far from being a unified notion (e.g., Neisser, 1988). This holds also true for different facets of the self, which may be at issue in social interaction. As Bamberg (1997), LuciusHoene and Deppermann (2004), Bamberg and Georgakopoulou (2008), and Deppermann (2015) have argued, positioning of selves in narrative interaction can occur on at least two levels: A representational level concerning the autobiographical, told self, and a performative level concerning the interactive and emotional self of the teller. The performative self usually is much harder to pin down, because it is non-propositional and enacted. In everyday interaction, it is unusual to explicitly describe aspects of the partner's performative self. Psychotherapy is different: in their interpretations, therapists regularly topicalize aspects of the performative self explicitly, in particular those that the client does not seem to be aware of, but may offer insights into the client's problems. One environment in therapist's responses shift to the client's present performative self are autobiographical narratives by the client that serve to support a certain identity claim made by the client.

Such shifts are sensitive moments in the therapy. They imply that the therapist claims epistemic authority concerning the client's current feelings, motives, or the interpretation of their behavior. This is in contrast to the usual assumption in Western cultures that the subject has privileged access to the self (Heritage, 2011; Gertler, 2020). Drawing on video recordings from three psychodynamic therapies (tiefenpsychologisch fundierte Psychotherapie) with 25 sessions each, in this paper, we analyze five extracts in which the therapist's interpretation shifts to the performative self of the client in response to a client's story. We first introduce Positioning Theory as an approach to conceptualize and study the self in (narrative) interaction on the basis of audio and video recordings (section Positioning in Narrative Interaction). Section Client's Self-Positioning and Therapist's Shifts to the Performative Self lays out the generic sequential structure of episodes in psychotherapy in which therapists shift from clients' autobiographical narratives to their performative self, including the ensuing negotiation of therapists' interpretations by both parties. After a description of data and methods used in this study (section Data and Methods), the main body of the paper is devoted to the in-depth analysis of five extracts in which therapists shift to the client's performative self in their sequential context (section Shifts to the Performative Self in Psychotherapy: Five Exemplary Cases). Section Conclusion summarizes and discusses the findings with respect to their import for psychodynamic therapy.

\section{POSITIONING IN NARRATIVE INTERACTION}

Narratives are the primary mode of self-reference in psychodynamic therapy (Boothe, 2004, 2010). Clients tell biographical episodes, recent events, dreams, etc. Yet, already early on, the psychoanalytic talking cure has involved not only recollection but also the focus on the client's repetition of entrenched behavioral patterns in the therapeutic situation (Freud, 1924[1914]). More recent approaches to psychoanalysis highlight this interactive dimension of psychotherapy as being crucial for change (Streeck, 2004). Well-known psychoanalytic phenomena like resistance, transference, and counter-transference operate mainly on the interactional level (Greenson, 1978). Yet, in modern versions of psychoanalysis, this highly asymmetric understanding of the psychotherapeutic relationship, which presupposes a knowing analyst vs. a client who is unaware of their psychodynamic motives, is replaced by a more symmetrical understanding of an intersubjective field to which both client and analyst are equally contributing. Interpretation in the post-bionian model of the analytic field "is no longer considered as the expression of the analyst's knowledge about the client, but as a multidimensional offer of meaning intended to bring new ideas and emotions to life at an intersubjective level" (Civitarese, 2020).

In this paper, we draw on Positioning Theory for the analysis of different facets of the self that are treated as relevant in psychotherapeutic interactions. Bamberg (1997) and Bamberg and Georgakopoulou (2008) distinguish between level-1 positioning, involving the self "as a character in the story" (Bamberg and Georgakopoulou, 2008: 380), and level-2 positioning, the way in which the teller "positions himself (and is positioned) within in the interactive situation" (Bamberg and Georgakopoulou, 2008: 385). Lucius-Hoene and Deppermann (2004) and Deppermann (2015) have elaborated this model, distinguishing representational positioning of the autobiographical, told self, and performative positioning of the emotional and interactive self. Performative positioning is implicit and importantly includes bodily displays. Both modes of positioning are manifested by different discursive practices:

- Representational positioning of the told self includes

- description of actions, feelings, thoughts, intentions, etc. by narrative clauses;

- ascriptions to present and past self;

- enactment by reported dialogue;

- reported statements by third parties;

- metanarrative comments on and categorizations from past or present point of view;

- Performative positioning of the emotional and interactive self includes

- claims to facets of identity by narrative performance and interactional conduct;

- affective displays by prosody, facial expression, gaze, etc.;

$\circ$ positioning vis-à-vis the interlocutor.

Positioning involves not only self-positioning but also otherpositioning, i.e., the ascription of facets of identity to the interlocutor (or third parties), which can also be done both by 
explicit representations or in a performative mode. Self- and other-positioning can imply each other, as, e.g., when adopting performatively the role of a teacher, the addressee is otherpositioned as a student.

Positioning Theory seeks for an analysis of identities as they become referred to and indexed in narrative talk-ininteraction. Conversation Analysis (Schegloff, 2007) equips us with the methodology of sequential analysis, which is needed to show how participants observably orient to situated facets of identity in their interactions and how they understand, treat, and negotiate identity displays. Positioning Theory is compatible with conversation analytic views on the self in interaction (Wilkinson and Kitzinger, 2003). It encompasses membership categorization (Jayyusi, 1984), but it can also address how participants recognizably orient to moral concerns of the self, i.e., the participant's face (Goffman, 1955). Yet, the Positioning approach goes beyond these two approaches by attending to the biographical and to the psychological dimensions of the self as well as they become manifest in interactional episodes (e.g., bodily self-perception, reflexive self-positioning, and ascription of feelings and motives; Deppermann, 2013).

\section{CLIENT'S SELF-POSITIONING AND THERAPIST'S SHIFTS TO THE PERFORMATIVE SELF}

Our study deals with narratives in psychotherapy that clients themselves interpret in terms of their personal identity. Thus, we deal with sequences of interaction in which the self is undoubtedly in focus for the participants. In the same way as Vehviläinen (2003) and Voutilainen et al. (2010) have shown, therapists in our data mostly initially respond with empathy or partial agreement with the client's identity claim. However, they never respond with unrestrained agreement or displays of reciprocity, e.g., by a second story about own experiences, as has been shown in other interaction types by Heritage (2011) and Kupetz (2016), but which would violate the neutrality requirement of the psychoanalytic technique. Instead, they provide candidate understandings (Weiste and Peräkylä, 2013), which may even be challenging (Antaki, 2012), and continue their turns by producing interpretations that attribute unconscious motives or unavowed feelings to the client (Greenson, 1978: 37-45; Peräkylä, 2008; Weiste et al., 2015).

The type of sequences we will discuss has the following shape:

- 1A: Story-telling: Client (CL) tells autobiographical story. 1B: Identity claim: CL interprets story in terms of identity ascription.

- 2A: Display of empathy: Therapist (TH) provides display of empathy and/or partial agreement.

2B: Interpretation: Therapist shifts focus to the client's present, performative self, pointing out identity aspects that contrast with, undermine, or reframe the client's selfascription. This shift to the performative level is brought about by focusing on the client's present behavior, their feelings (Peräkylä, 2008; Voutilainen et al., 2010), and/or the (unconscious) motives that make the client tell their story. The focus on the client's performative self can combine with a focus on how the client manages the relationship with the therapist.

- 3: Negotiation of the interpretation: Therapist and client negotiate the meaning or the validity of the therapist's interpretation (Peräkylä, 2005, 2010). This part will minimally consist of the client's response to the therapist's intervention $2 \mathrm{~B}$, but may extend to a larger negotiation of interpretations and ascriptions to the client; it can also include argumentative and narrative elaborations.

In this paper, we examine (1) how clients in psychodynamic psychotherapy interpret their own autobiographical narratives in terms of who they are (Bamberg, 2011), (2) how therapists respond to narratives by interpretations shifting to clients' performative self, and (3) how both parties negotiate the meaning and the validity of the therapist's interpretation of the client's self, focusing on whether both parties manage to arrive at a shared understanding of the client's identity, motives, and feelings.

\section{DATA AND METHODS}

We draw from two psychodynamic focal therapies with 25 sessions each, video-taped at the Medical Faculty of the University of Freiburg, Center for Psychiatry, Psychosomatic Medicine and Psychotherapy in 2017-2018. Excerpts 13 from the first therapy include a male client in his late 60's suffering from depression and a functional pain syndrome subsequent to the death of a family member. The young female therapist was still in her analytic training. Excerpts 4 and 5 are from the second therapy with a young woman in her 20's suffering from psychogenic seizures. The therapist was a psychoanalytically trained senior staff member.

All sessions were exhaustively coded for all occurrences of different types of therapists' responses like understanding checks, repetitions, formulations, and interpretations. Fiftyfive instances of therapists' interpretations were transcribed according to GAT2 (Selting et al., 2011, with selected additional multimodal annotations, Mondada, 2018; see Appendices A, B) together with their sequential context (with a duration between 1:59 and 7:01 $\mathrm{min}$ ), i.e., preceding client's narratives and descriptions and following negotiations of the interpretation. All 55 extracts were analyzed by the three authors together using Conversation Analysis with a focus on sequential organization and turn design. Among the 55 extracts, 5 extracts (out of 10) in which the therapist shifts to the performative self of the client have been chosen for this paper. 


\section{SHIFTS TO THE PERFORMATIVE SELF IN PSYCHOTHERAPY: FIVE EXEMPLARY CASES}

In the following, we analyze in depth five extracts in which therapists respond to clients' autobiographical self-positioning by shifting to performative aspects of client's current self. We have chosen extracts that give evidence of the various dimensions of the performative self that therapists address in their interpretations:

- Unconscious motives that inform client's storytelling (section Redefinition of the Motives for Storytelling: From IdentityDisplay to Defense Mechanism),

- emotions that are in contrast to client's explicit selfpresentation (section Inference From Presuppositions in the Client's Story: From Rational Self-Presentation to Emotional Distress),

- the client's way to conduct the interaction with the therapist (section Interpreting the Client's Way of Designing the Psychotherapeutic Relationship: Claiming an Analogy Between Agentive Self-Relationship and Interpersonal Relationship),

- different objects or causes for the client's emotion (section Observing Non-verbal Conduct: Focusing on an Emotion and Shifting its Object),

- a challenge of the authenticity of the client's representational self-positioning (section Summarizing Impressions From Client's Talk: Challenging the Authenticity of the Performance).

Each section closes with a conclusion concerning the positions that the participants accomplish with respect to the client's self in the extracts: client's representational self-positioning is summarized and related to how the therapist other-positions the patient by shifting to the client's performative self.

\section{Redefinition of the Motives for Storytelling: From Identity Display to Defense Mechanism}

Extracts 1-3 are from the first therapy with a young female therapist and an elderly male client. One of the recurrent topics of the sessions are CL's conflicts with authority figures, which had also been discussed before extract 1 starts. The client tells a story about a conflict with a superior at work as evidence for how he acquired psychological strength. The therapists shift to the motives for the client's storytelling ${ }^{1}$.

${ }^{1}$ Transcript headers designate the therapy series (I or $\mathrm{C}$ ), number of session, and beginning and end time of the extract within the session.

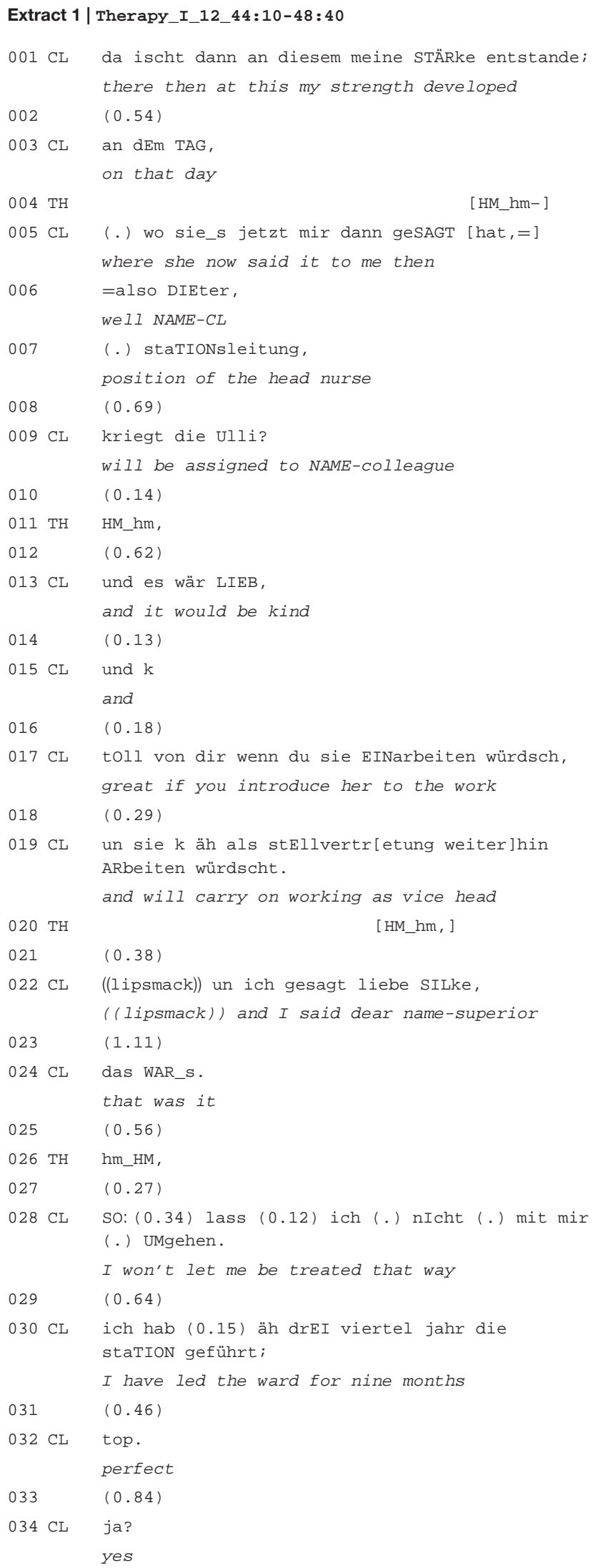




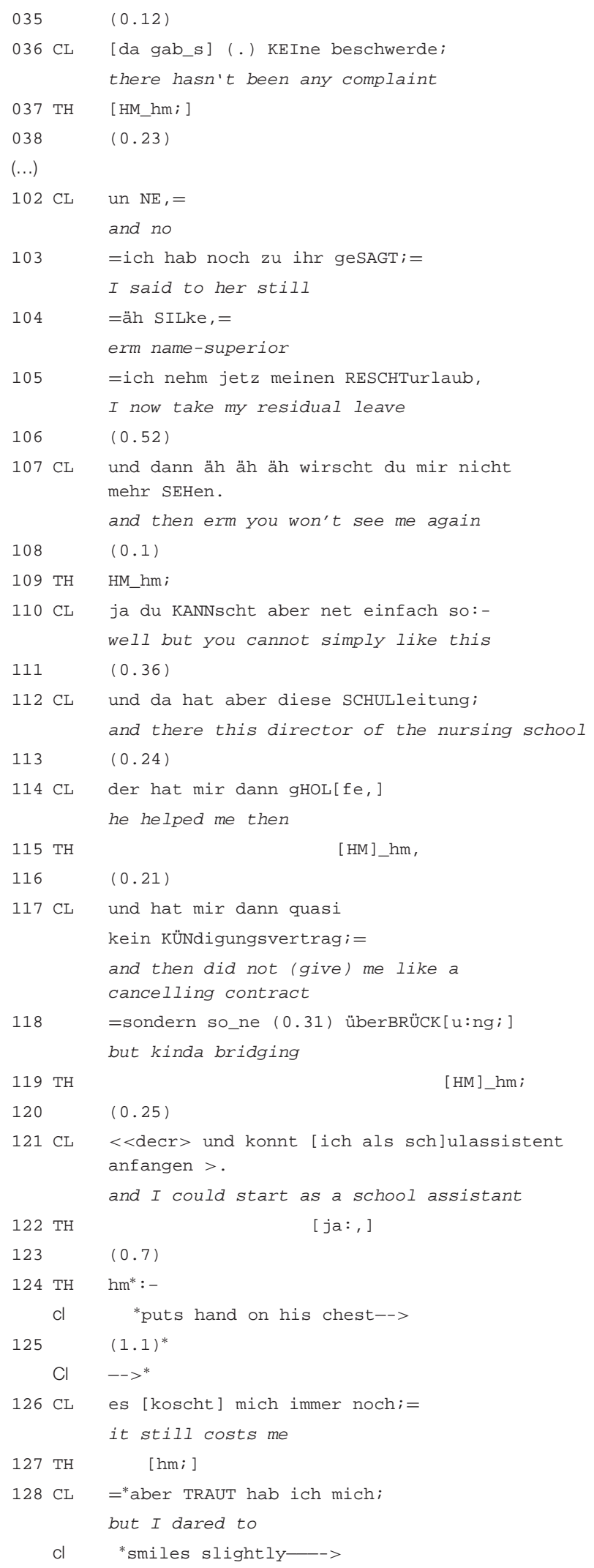

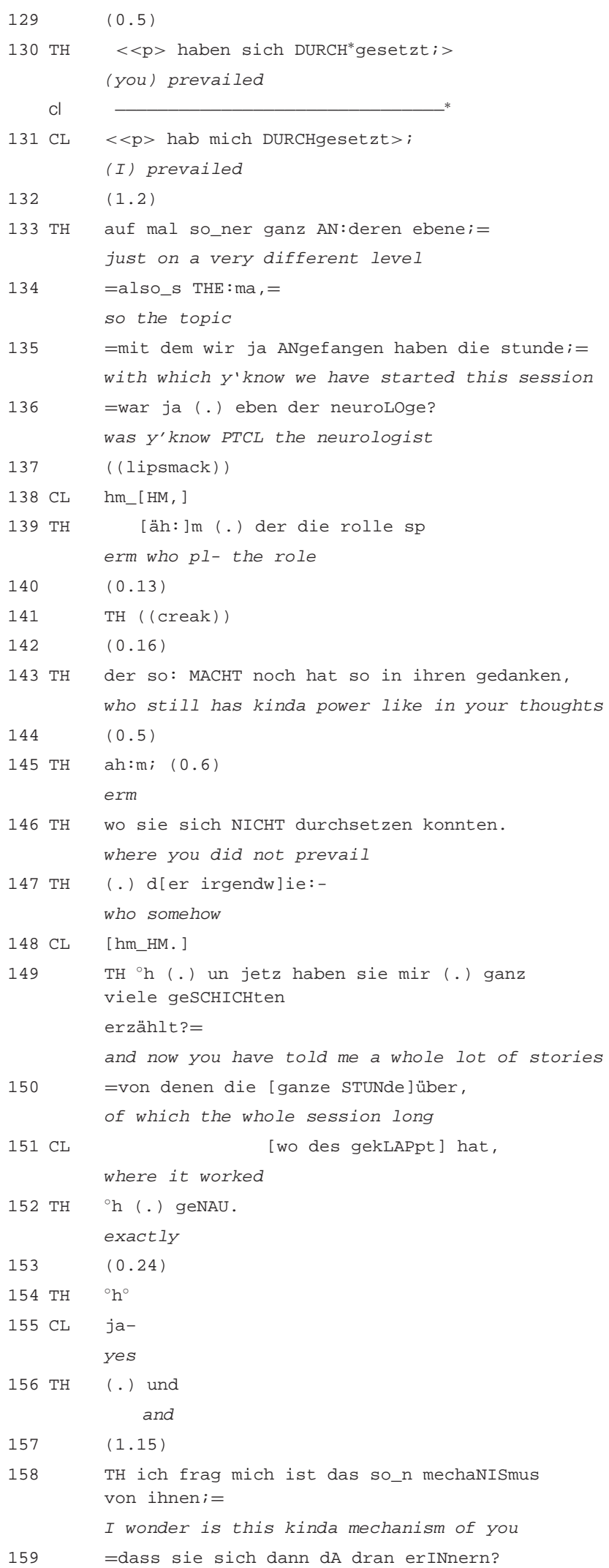


that you remember that then

${ }^{\circ} \mathrm{h}$ ((lipsmack)) u:m (.) sich so !SE:LBST! (.)

äh:m (0.21) zu zei:

((lipsmack)) erm in order to erm sho- yourself

this way

(.) also nochmal AUFzuzeigen:; =

I mean display once again

=da gIbt_s auch situationen wo ich das meistern koNnte?

there are also situations in which I (= client) could cope with that

(0.53)

damit sie sich weniger SCHWACH fühlen?=

so that you feel less weak

=in den ANderen situationen; =

in the other situations

=so was ist (0.64) die RoLle (.) dieser geschichten und dieses

(.) dieses erzählens [da(bei), ]

so what is the role of these stories and this this telling there

isch_ne SAche, [das isch_ne] des

this is a this is a thing

(0.4) da gebe sie mir jetz en SCHLÜSsel?

there you now give me a key

(0.44)

TH hm_HM,

(0.2) weil sie des jetz SAge,

because you say this now

$$
(0.6)
$$

des HILFT mir,

this helps me

(0.35)

weil dann werde ich in zukunft, =

because then I will in the future

=wenn da mal wieder irgendwie was ISCH oder so,

if there is just again something or so

${ }^{\circ} \mathrm{h}$ (.) werde ich mich (.) ÖFter mal an

diese situationen erINnern.

I will just remember these situ ations more often

(0.52)

$\mathrm{TH}{ }^{\circ} \mathrm{h} \quad\left[{ }^{\circ} \mathrm{h}\right]$

[wo isch] STARK war;

when I was strong

$(0.73)$

ich hab das nich ich ich [((knarrt))]

I have that not I ((creak))

$$
\text { no this }
$$

[NE des:]

ich glaube ich wollte jetz erstmal nur so (.) in FRAge stellen.=

I guess I wanted now first just only

kinda question

=was sie damit MACHen; =

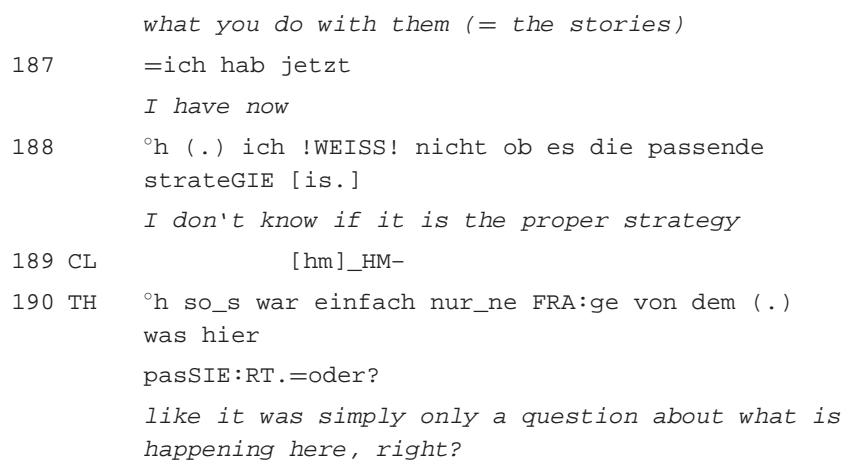

\section{Client Tells a Story of Prevailing Over an Authority} Figure and Interprets it in Terms of Strength (001-131)

The story preface: ("my strength developed on that day," "da ischt an diesem meine STÄRke entstande; an dEm TAG," 001003) projects an autobiographical key narrative. It is a story about pride and self-assertiveness when facing a threat of devaluation: The client considers himself to be treated as unfair and disrespectful, because he is not appointed as a ward nurse, although he fulfilled this position for 9 months perfectly well and without any complaints (30-36), was praised by the doctors and proved to be a responsible and strict leader of his team (between 38 and 102, not shown). The climax of his story is a reported interaction with his superior, in which he rejects the request to introduce the new ward nurse to her work; instead, he cancels his job on the spot (103-110) and changes to another position that was offered to him in a neighboring nursing school (112-121). The final morale frames it as a story about courage (124-128) in the face of an unjust authority, who does not respect him.

\section{The Therapist's Response: Inquiring Into the Motivation for Telling Stories of Strength}

As a first reaction, the therapist shows understanding and empathy by collaboratively formulating the gist of the story as "you prevailed" (130), which is confirmed by the client's repeat (131). The therapist then announces to switch to a "completely different level" (133). She refers back to the stories that the client told over the course of the sessions (135-152) and puts forth the hypothesis that the client tells stories of strength in order to fight feelings of weakness (149-165). In psychoanalytic terms, the client's stories are interpreted as a variety of the defense "mechanism" (158) of reaction formation (Freud, 1937). This can be conceived of as resistance against facing the painful feeling of being left out. The categorization as a "mechanism" (158) of the client implies that there is a motivational process the client is not aware of. The therapist's intervention is clearly not affiliative. It treats the kind of stories the client tells as a behavior in need of psychological analysis. However, the psychoanalytic term "mechanism" may not be transparent to the client, who therefore misses that it hints at questionable motives in need of further exploration (see step 3). 


\section{Ensuing Negotiation: Useful Self-Management Strategy vs. Object of Motivational Inquiry}

The client does not take the therapist's intervention up as a cue for questioning his hidden motives. Instead, he treats it as a recommendation of a self-management technique to fortify his identity when he feels shaken (168-181). The therapist disclaims that it was her intention to recommend using stories of strength as a self-management technique. By his third-position repair (Schegloff, 1992), she rejects the client's response as resting on a misunderstanding of her interpretation; instead, she insists on questioning the use of this strategy (183-190).

\section{Self- and other-positioning in extract 1}

In Extract 1, the client positions his told self mirrored by the perspectives of third parties: $\mathrm{He}$ is treated disrespectfully by superior vs. praised by doctors and supported by the head of the nursing school. Third parties serve as warrant of his entitlement to the position he is denied and to his moral rights against his superior, who disrespects him. The client explicitly claims and narratively displays an identity of strength, which he has acquired by a courageous act. The story is a biographical key story, which describes a change in the client's identity by his own agency against all odds and which establishes an important link between the client's former and his present self. The story is presented as a warrant for the factuality of his identity claim: the representational level of the story is treated as primary. The client positions himself by performance as well: His past self is re-enacted with syntonous affect (indignation, anger), and he displays pride by smiling when formulating the morale of the story. Interactively, the client calls for recognition of his courage and his achievement, inviting affiliation with his identity claim, maybe even fishing for the therapist's praise.

The therapist displays empathy with the client and his claimed self of strength. Nevertheless, she shifts the focus and treats the performative level as primary by interpreting the client's story not as a factual story about the becoming of his identity (= representational positioning), but as a performative, strategic self-presentation, whose function is to be questioned, because it serves to avoid facing experiences and feelings of weakness.

The levels of positioning that client and therapist treat as being focal are at clash. While the client focuses on the biographical becoming of his identity, the therapist treats the motivation for claiming this identity as more important. Yet, the client does not understand the therapist's intervention as a cue to explore his motivations in more detail. Instead, he takes it up as a recommendation, which supports the psychological usefulness of his identity claim as a means to enhance his agency and well-being.

\section{Inference From Presuppositions in the Client's Story: From Rational Self-Presentation to Emotional Distress}

In extract 2, the therapist's interpretation focuses on an emotion (sadness) that contradicts the client's overt claim (acceptance) but is treated as being presupposed by the client's word choice. Already in the first session, the therapist and the client talk about his loss of bodily strength and endurance because of aging. Comparing himself to others who are worse off, the client stated: "Ich muss zuFRIEde sein." ("I must be satisfied," 05:54). Afterwards, the client told about the need to be cautious because of problems with his prostate gland. After the client concludes his story with an interjection that expresses concern ("HA:I yai yai," 03), the therapist refocuses on the client's prior claim that he has to be satisfied with his health condition, and casts it into doubt (13-15).

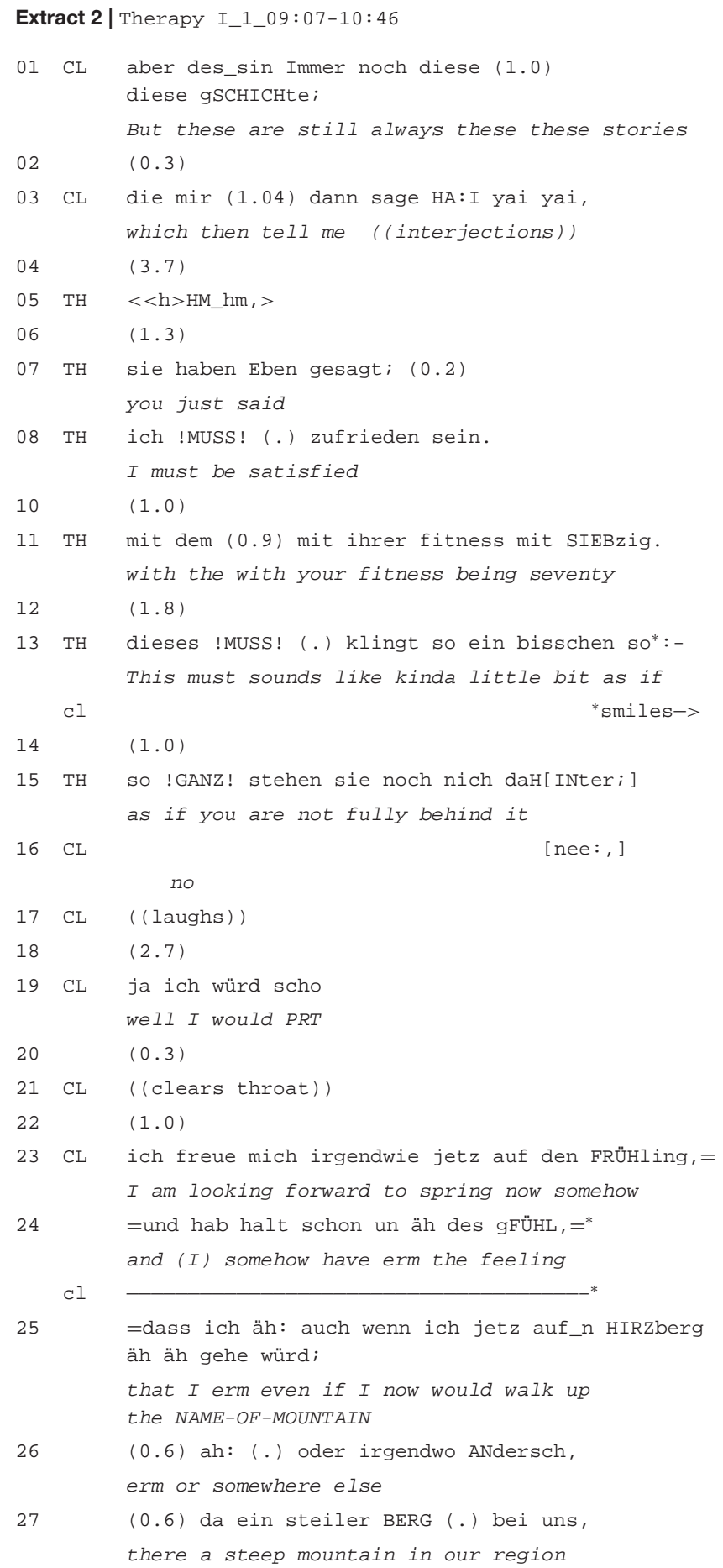


(0.5) äh da dass ich ((knarrt)) das mit dem: erm there that I ((creaks)) the thing with the ah: mit der (0.3) i es GE, erm with the sacroiliac joint $(0.3)$

HM_ $[\mathrm{hm}$,

[sehr wahr]scheinlich (.) ah: : (1.3)

very probably erm

proBLEme kriegen [würde.]

(I) would run into trouble

$$
(0.66)
$$

\section{(1.5)}

genau des_so diese verNüNftige seite die zu ihnen sagt,

exactly there is this rational side which says to you

(2.2)

[isch s]o_ne ambivaLENZ;

(it) is kind of an ambivalence

[aber ]

but

geNAU. $=$

\section{exactly}

but what interests me is just a
=so_n bisschen die emotionAle, $=$

kinda little bit the emotional

=vielleicht auch die TRAUerseite;

perhaps also the sadness-side

$\mathrm{hm} \_[\mathrm{HM} ;]$

[di]eses ABschiednehmen;

$$
\text { this saying goodbye }
$$

$$
(0.8)
$$

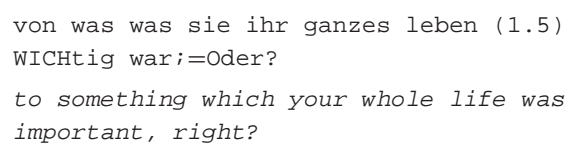

the devil knows what else

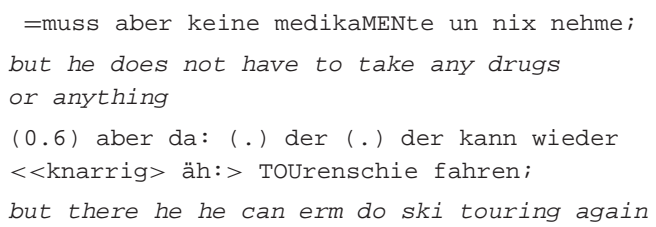

\section{Client's Story (Before the Extract Until Line 03)}

The client talked about health problems, his concerns, the need to be cautious, and his acceptance of his health condition, given that others are worse off.

\section{The Therapist's Response: Therapist Doubts That Client Is Satisfied With His Health Condition (05-15)}

The therapist quotes the client's earlier claim that he must be satisfied (07-11) and highlights his use of the modal verb "muss" ("must," 08), which expresses constraint (Zifonun et al., 1997, 1881-1923). She interprets the choice of the verb as making perceivable ("klingt so," "sounds like," 13) ${ }^{2}$ that the client is not fully emotionally ready to accept his situation, or, alternatively, not fully convinced that he has to accept it (13-15). This interpretation makes an unavowed emotion explicit (Peräkylä, 2008; Voutilainen et al., 2010) and is clearly designed to achieve intersubjectivity by referring to common ground concerning the client's narrative action in order to persuade him (Weiste et al., 2015). Yet, the therapist thereby changes from the client's explicit self-positioning to an impression she has gained about his present emotional and cognitive stance toward his health condition that the client is taken as not having communicated, but given off (Goffman, 1959) by his linguistic choice.

\section{Ensuing Negotiation: Ambivalence Between Desire and Physical Limitations vs. Focus on Sadness About Loss (16-35)}

In overlap with the therapist's interpretation, the client starts to smile, agrees (16), and then laughs slightly (17), which seems to index that he feels being understood. He continues by deploying the imaginary scenario of looking forward to climbing a high mountain (what has been his favorite hobby), stating that he would expect to have problems with his sacroiliac joint (17-35). The therapist confirms and categorizes his account as expressing his rational side (38), thus constraining its validity as expressing only one part of the client's self. The client, in turn, concludes that there is an ambivalence (between his desire to do sports and concerns about limitations of his health condition, 40). By marking a shift in perspective ("the other side," 43), the therapist again changes focus to the client's emotions, now explicitly introducing sadness about having to say farewell to well-beloved habits (43-49). Using the format "what interests me is X" (43), the therapist does not explicitly claim that the client is sad about having to say farewell, nor does she explicitly ask if this is the case. Rather, she establishes this emotional state as a thematic focus (43-49). Using the demonstrative article ("this saying goodbye,"

${ }^{2}$ See Stukenbrock et al. (submitted) for the use of meta-perceptual verbs in therapists' interpretations. 
47), she presupposes that it is relevant for and known by the client, urging him to elaborate with a tag (49; König, 2020). The client grants the therapist's intervention by a concessive particle (50); he expands his turn by a story about his brother, who, in contrast to the client, is still able to practice physically demanding sports, although he suffers from various illnesses as well (54 until beyond the extract). This story of social comparison implicitly avows discontent and the feeling of injustice of not being able to perform any more like significant others of about the same age. The client thus partially aligns with the therapist in exploring his emotions concerning physical limitations further, however, without dealing with the emotion of sadness about loss in particular.

\section{Self- and other-positioning in extract 2}

The client positions himself as a person who is fond of doing all sorts of physical activities and sports, but who is concerned about his condition because of health problems that have increasingly developed with age. He conceives of himself as being in an ambivalent position, torn between the desire for bodily activities and the acceptance of increasing physical limitations.

While confirming the client's self-positioning and his pragmatic orientations, the therapist focuses on the client being emotionally more affected from the sadness about losses related to aging than he seems to admit. Her first intervention closely builds on the client's prior words and, drawing on a semantic presupposition of his statement, she infers emotional trouble on his part concerning age-related changes in his health condition (07-15). As the client does not take up the issue of exploring the emotions that might cause his "not fully being behind" his acceptance, the therapist explicitly states "sadness about loss" as a topic, an emotion that she at least tentatively attributes to the client.

The explicitation of the inference from the client's linguistic choice is thus a means to cue the client's self-exploration in the direction of the therapist's hypothesis. As the client does not take this direction, in her second intervention, the therapist formulates the inferred emotion explicitly, thus showing more clearly that she ascribes to the client a motive or feeling that he did not address yet.

\section{Interpreting the Client's Way of Designing the Psychotherapeutic Relationship: Claiming an Analogy Between Agentive Self-Relationship and Interpersonal Relationship}

In extract 3, the therapist draws an analogy between the topic of the client's story (self-control) and his interactional conduct (his attempt to control the therapeutic relationship).

Throughout the therapy, the client repeatedly reports about measures he takes in order to preserve his health. The therapist comments on one of these stories by ascribing to him that he acts "well-organized, well-reasoned and controlled" (082-084).

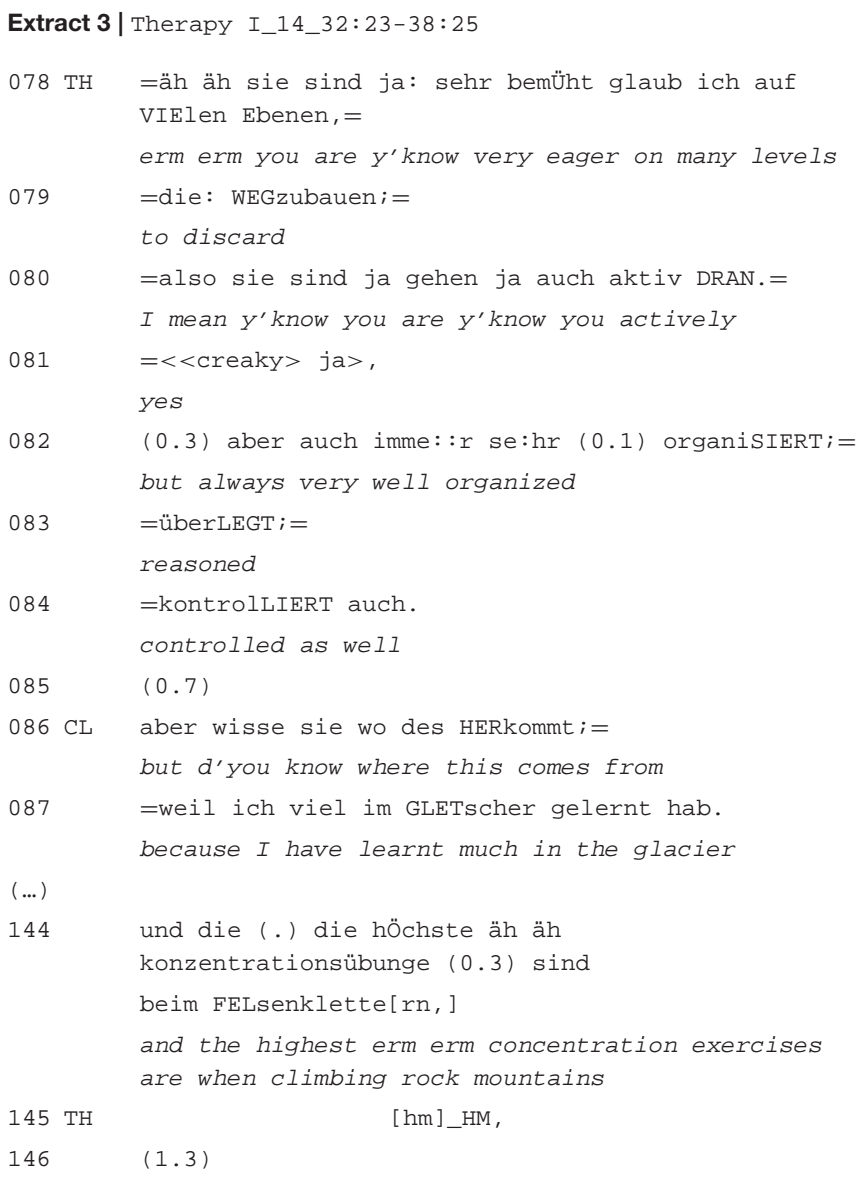

The Client's Story: Autobiographical Self-Positioning as Acting With Care and Concentration

The client seems to receive the therapist's comment about him acting well-organized, reasonable, and controlled (082-084) as praise. He responds by telling a story about how he learned to act with great care and concentration when climbing in the glaciers (086-144). This story expands a series of autobiographical stories in which he portrays himself as exerting agency (080) in a cautious and well-planned manner (082-084).

\section{The Therapist's Response: Shift to the Way in Which the Client Manages the Therapeutic Relationship} The therapist first confirms the client's autobiographical identity claims (147-161), but then shifts to his behavior in the therapy (162-176).

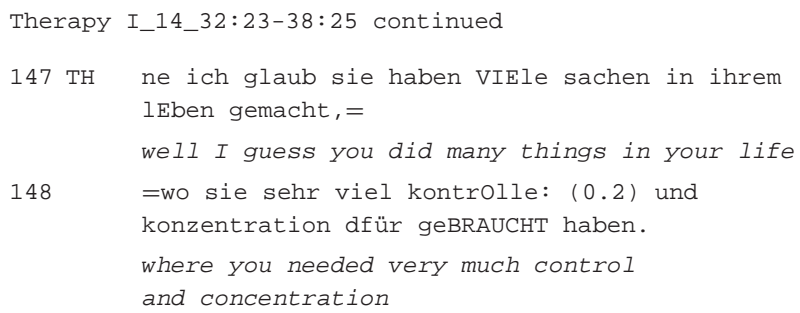




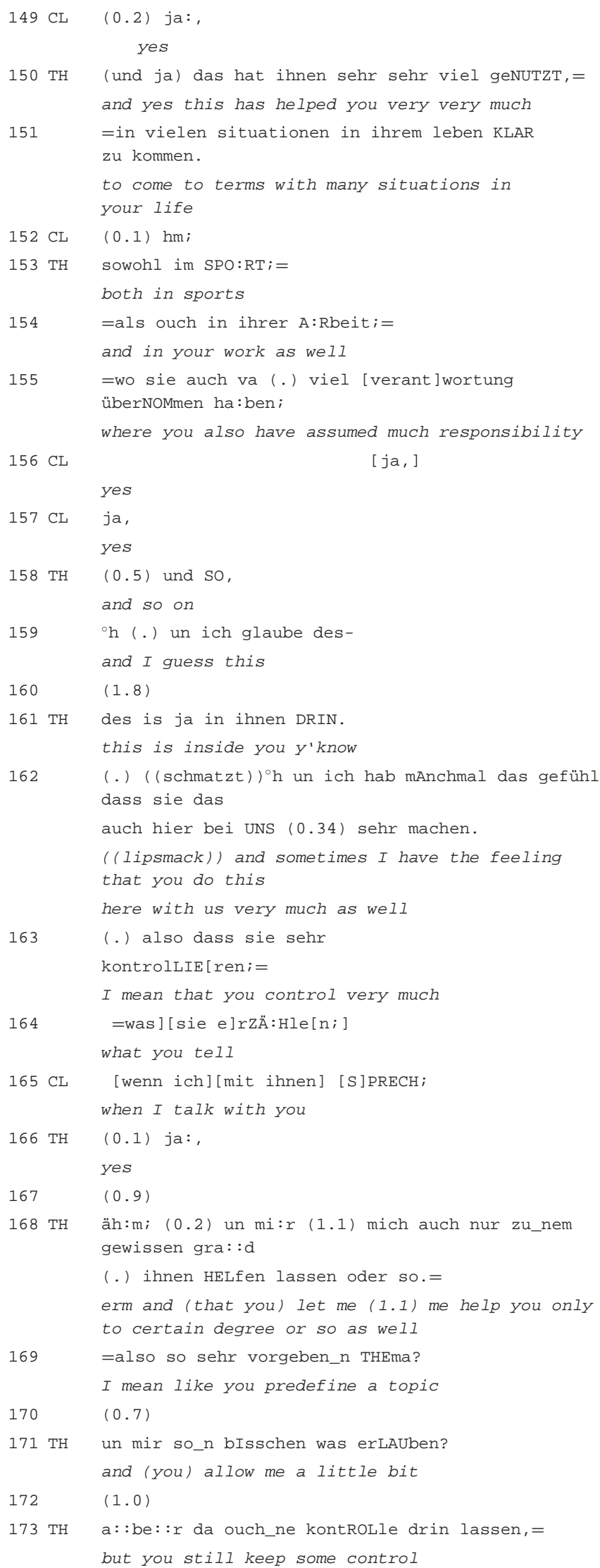

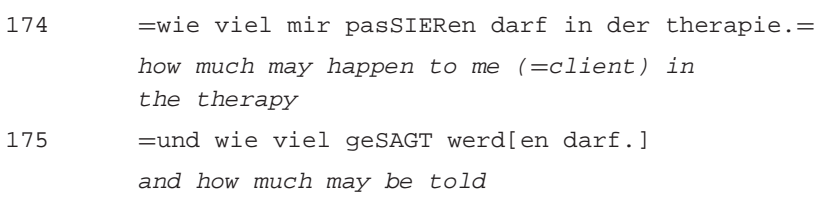

Re-using her notion of "control" as a leitmotif of her interpretation of the client's self $(084,148,163,173)$, the therapist confirms that the client has come to terms successfully with many situations in his life (148-155) by "very much control and concentration" (148). She concludes that this strategy is deeply rooted in the client's self (159-161). She continues by drawing an analogy between the way in which the client controls himself and his life outside of the therapy with his verbal behavior in the therapy and the way he manages the therapeutic relationship (162-175). She claims that the client controls topics and the ways in which they are talked about $(164,169,175)$ in a way that limits the scope of therapeutic help from her $(168,176)$.

\section{Ensuing Negotiation: Denial of Limited Openness vs. Claim to Resistance Out of Fear}

The client insists on the wish that the therapist helps him (177-186) and affirms that he wants to engage fully with the therapist (188-189). Yet, while accepting the authenticity of the client's wish (267-275), the therapist reframes her assumption that the client resists against giving up control (277-289).

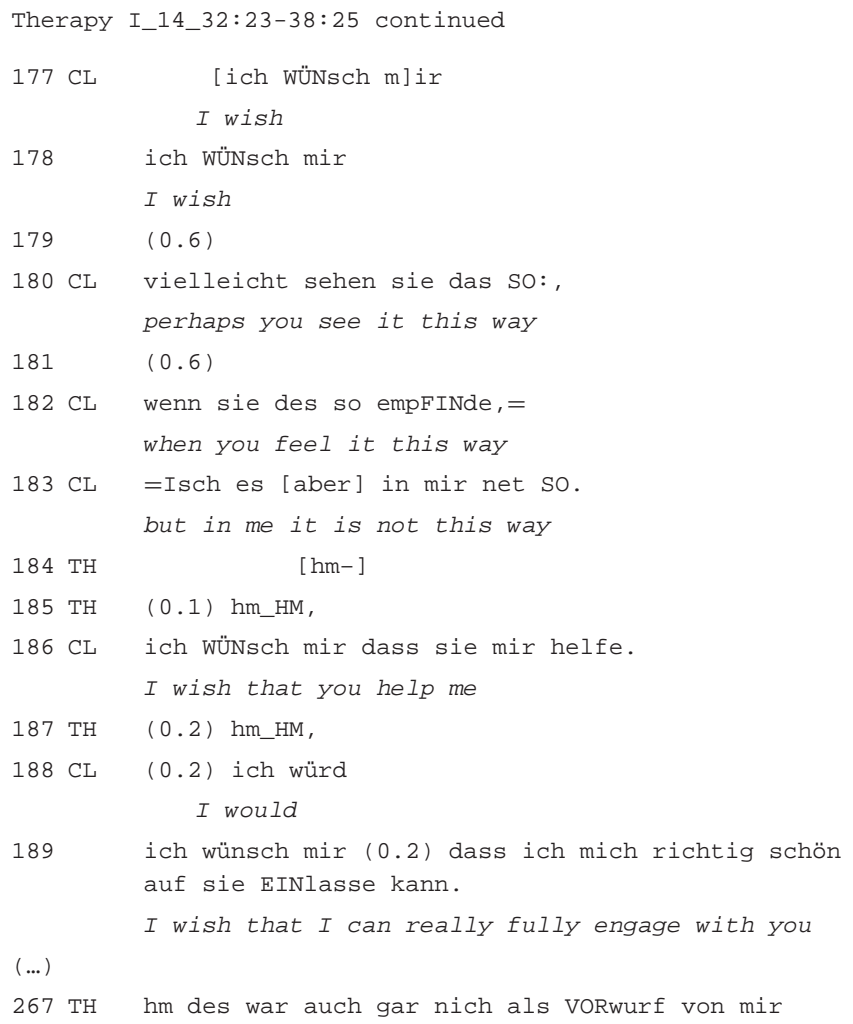




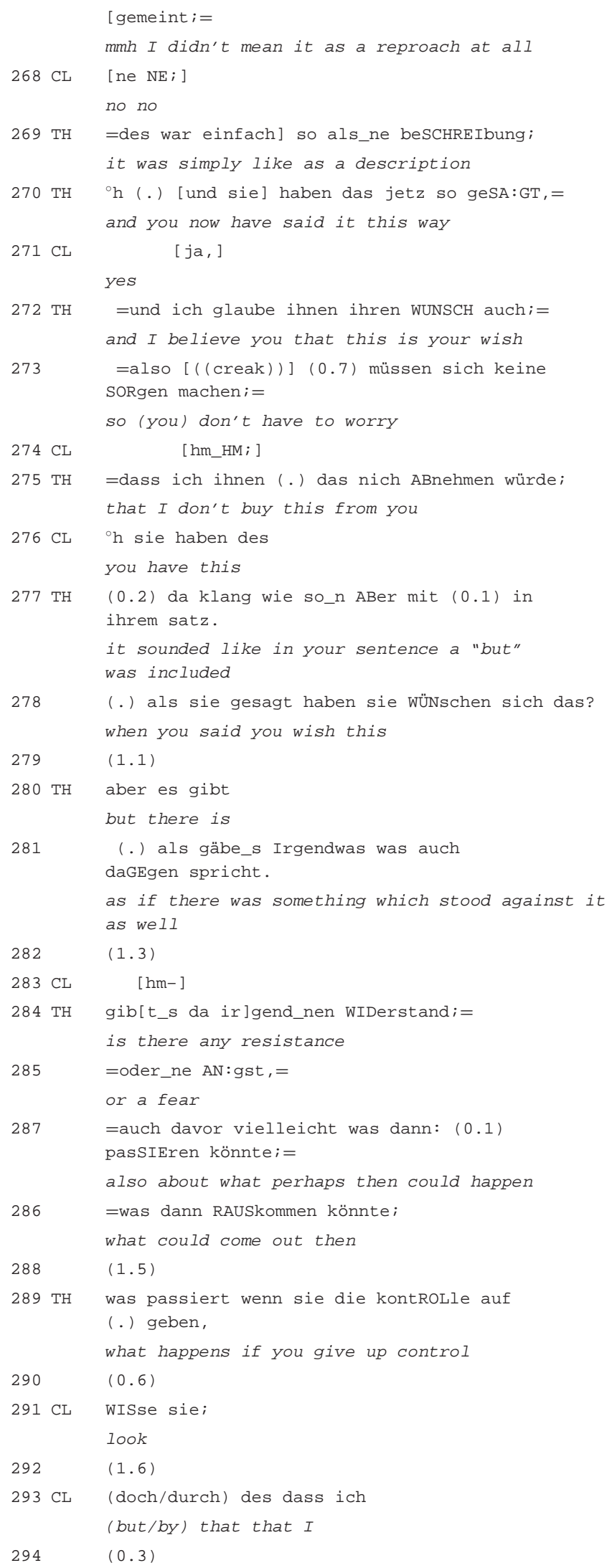

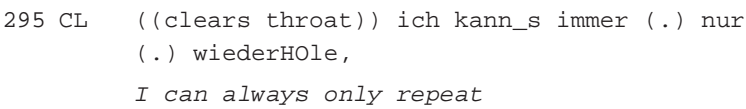

In response to the therapist's ascription that the client controls and limits topics (162-176), the client claims his wish to be helped by the therapist and to engage fully with the therapist (177-189). Therapist and client thus express oppositional views on the present, interactive self of the client concerning his aim for interactional control and openness. The client's lengthy account of his wish to open up fully to the therapist, which is continued in the elided part of the excerpt (190-266), is responded to by the therapist by an overt action ascription: she denies that her prior action was to be understood as a "reproach," but recategorizes it as a "description" of the client's way of interacting in the therapy (267-269). She adds that she believes in the seriousness of his wish to be helped by her (272-275). Both concessions are designed to discard the impression that seemed to underlie the client's affirmations, namely, that the therapist attacks the client's moral self in not believing in his authentic and unrestrained engagement in the therapeutic relationship. As before (078$084,147-161)$, the therapist takes care to explicitly confirm the client's own positive identity claims (267-273). Yet, these affiliative affirmations are only preliminaries to insisting on her prior ascription that he is afraid of losing control (277-291). She first claims that the client "sounds" (277) as if his talk included an unspoken concessive part, a "but" (277). This time, the therapist not only reiterates the ascription of "control" to the client (289) but also adds more far-reaching motivational ascriptions, asking whether there is "resistance" (284) or "fear" (285) in the client against giving up control. Although the therapist's interpretation is couched in terms of an interrogative, her insistence on the topic and the evidence from the sound of his talk clearly show that she assumes the client to exhibit resistance. Starting in 291 (and continuing beyond the extract), the client reaffirms that he fully engages in the therapy, while conceding that he may not seem to be as "relaxed" as the therapist might want him to be.

\section{Self- and other-positioning in extract 3}

The client positions his autobiographical, told self as acting cautiously, planfully, and with a large amount of concentration, i.e., as a person with a high degree of agency. In response to the therapist's challenging ascriptions, he explicitly positions his present, interactive self as engaging fully with the therapy in order to get optimal help.

The therapist fully affiliates with the client's explicit selfpositioning, which she explicitly confirms. She uses the psychoanalytic technique of proving the lingering relevance of past experiences for the client's present self by claiming that the client re-enacts biographically entrenched patterns of interaction in the therapy (Levy, 1998). By this, the therapist shifts from the level of the client's autobiographical self-positioning to the client's interactive, present self by way of analogy. The client is otherpositioned as acting in a way that is unnoticed by himself and contradicts his explicit claims. The therapist makes a distinction 
between believing the client's intentions (not to control and restrict his performance in therapy) and her assumption that the client does not act according to what he claims, thus introducing the distinction between a conscious and an unconscious self of the client as an interactionally relevant reality.

Over the extended negotiation about the relevance of "control" to the client's actions beyond and within therapy, therapist and client do not reach an agreement about how to conceive of the client's interactive self. While both agree on the client's explicit self-ascriptions, the therapist claims that there are additional unconscious motives, which run counter to the intentions of the conscious self. Yet, the therapist unpacks these motivational ascriptions only after the client has not accepted her ascription of a controlling behavior in the therapeutic context and has not engaged in self-exploration concerning the possible motif that the therapist has ascribed to the client.

\section{Observing Non-verbal Conduct: Focusing on an Emotion and Shifting its Object}

In extract 4 , the therapist focuses on an emotion (sadness) that the client expresses mainly non-verbally and he shifts the object of the emotion to a more self-related concern.

Extracts 4 and 5 come from the second therapy with a senior male therapist and a female client, who suffers from psychogenetic seizures. The client has just told her boyfriend that she breaks up their relation. She talks about her concern that, after they separated, she won't be able to help him anymore.

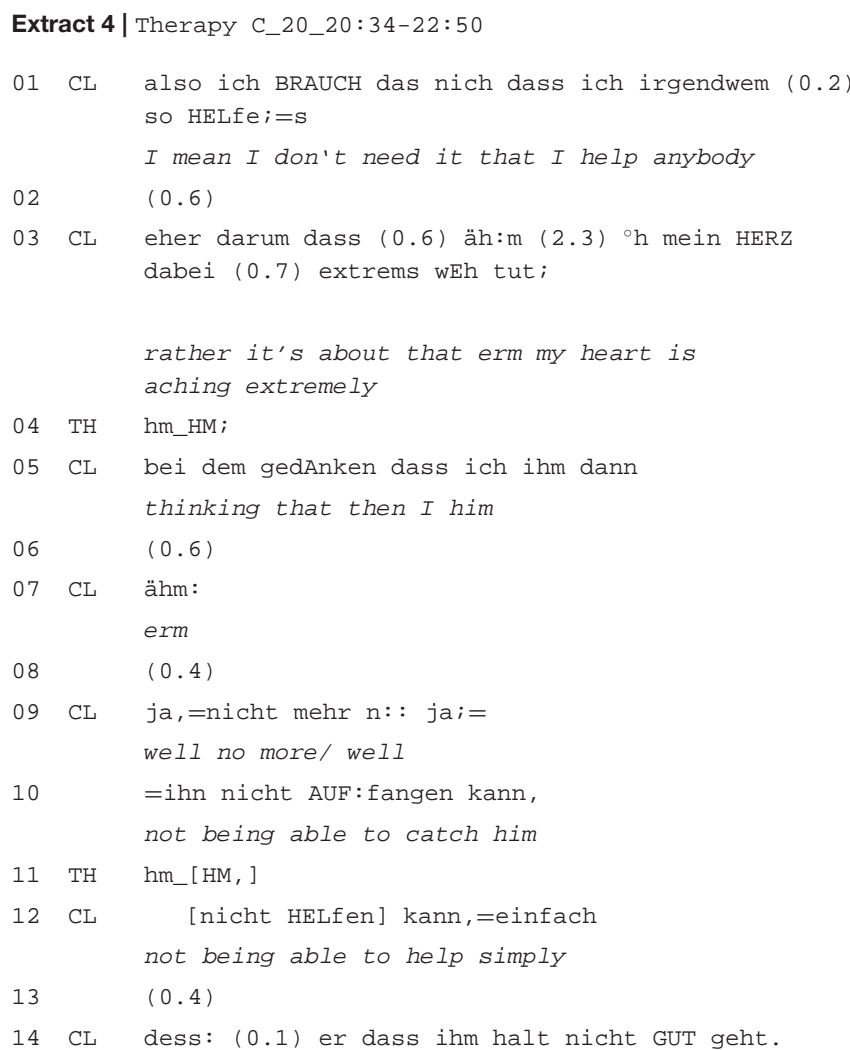

that he that he just is not well

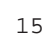

16

17 C

19

22

23

24

$25 \mathrm{C}$

26

27

28

29

30

$30 \mathrm{TH}$

31

32

33

(2)

34

35
(0.1) hm_HM,

(0.8)

dass dass er

that that he

(1.2)

ich könnte locker drauf verzICHten,

I could easily do without

((aborted laughter)) <<laughingly $>$ ihm zu HELfen $>$; =aber

((laughs)) helping him but

$(0.8)$

[äh:m:]

erm

[HM_hm, ]

(1.6)

nur wenn_s ihm dann GUT geht.

only if he is well then

(0.5)

TH HM_hm;

$*(3.0) *(3.5) *(3.7) *(2.7) *(1.5) *(6.5) *$

Cl *nods $3 x^{*} *$ nods $2 x^{*}$ crisps lips* *crisps/bites lips*

* $(5.7) *$

*eyes fill with tears*

((lipsmack)) (.) so_n bisschen traurig macht sie das SCHON dieser gedanke.=ne?

it makes you kinda little bit sad though

this thought

(0.5)

$(($ lipsmack $))<<f>j a: ;>=$

yes

${ }^{*}$ auf jeden FALL, $>$

definitely

cl *smiles- $->$

$[$ jaha; ]*

yes

Cl $->^{*}$

ja [da]ss ihre wege jetzt auseinANder gehen, =

well that you will be going separate ways now

=dass sie (0.76) ihm danach nich (0.46) nich mehr

that you him afterwards no no more

(0.3)

((lipsmack)) $<<$ creaky $>$ ja $>$.

yes

( (lipsmack)) HELfen können.

will be able to help

(0.2) ja.

yes

(6.5)

CL ${ }^{\circ} \mathrm{h}$ da muss ich halt wIrklich auf mich AUFpassen,

I really just have to take care of myself

$(0.3)$

CL wenn ich dann zu HAUse bin,

when I will be at home then 


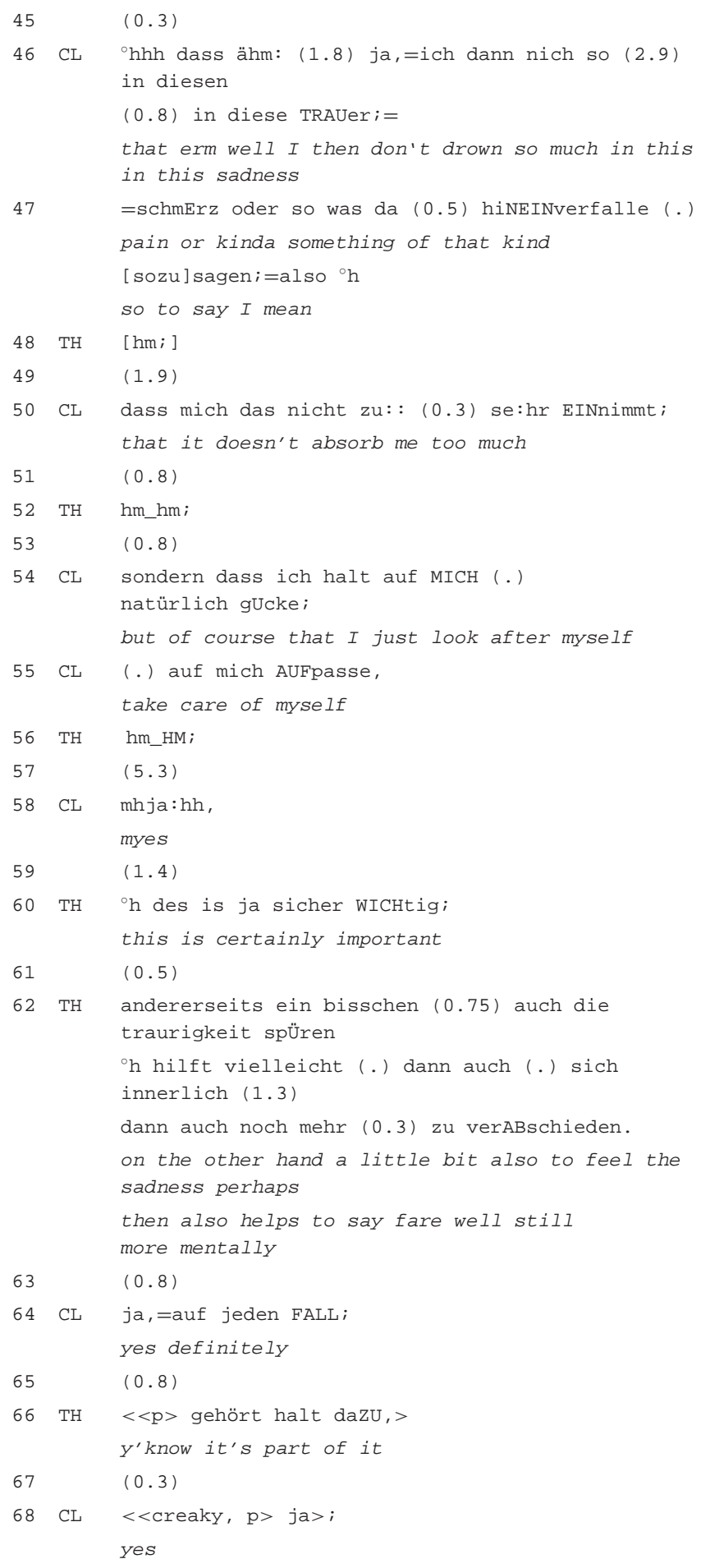

\section{The Client's Story: Concern About Her Boyfriend (01-25)}

The client had told about her boyfriend's eating disorders and his problems to come to terms with his life. She tells that she feels bad when thinking that she won't be able to help him anymore in the future after they split. In the lengthy pause that emerges after her account (28-29), the client nods several times and looks away from the therapist; she crisps and bites her lips; her eyes begin to fill with tears.

\section{The Therapist's Response: Focus on the Client's Emotion (30-39)}

The therapist provides an interpretation that assigns an explicit emotional interpretation to the client's non-verbal conduct (cf. Muntigl and Horvath, 2014): "it makes you kinda little bit sad though this thought" (30). The modal particle "schon" indexes a concession that the therapist expects the client to make, thus showing that he conceives his interpretation to be at least partially different from her explicit self-presentation (30). The client confirms without reserve, slightly smiling (32-34). However, the therapist continues his turn by explicitly adding a formulation of the object of her sadness, namely, the separation from the boyfriend (35), which is different from what the client had talked about before, i.e., the inability to support her boyfriend anymore (see 09-12). Still, the therapist then realigns with the client's prior focus of not being able to help anymore (36-39).

\section{Ensuing Negotiation: Joint Shift to Client's Self-Related Emotions and Need for Coping}

Taking up the therapist's ascription of sadness ("traurig," $31 \rightarrow$ "traUer," 46), the client elaborates on it by claiming that she will have to take care of herself by not letting herself drown in this emotion (42-55). The therapist explicitly agrees (60), but then claims that the client will need to face the sadness about the end of the relationship in order to be able to say farewell and psychologically cope with it more comprehensively (62). Both agree (64-68).

\section{Self- and other-positioning in extract 4}

The client first explicitly positions herself as being distressed by not being able to comply with the exigencies of her moral ideal self concerning the support she should provide her boyfriend.

The therapist does not question the explicit self-positioning of the client. Rather, he gradually shifts the focus away from the boyfriend and the client's moral self to her own emotions (Peräkylä, 2008; Voutilainen et al., 2010) caused by the experience of the split-up and the need to cope with them properly. This change is managed by attending to the client's performative, non-verbal displays and by topicalizing their emotional content.

The therapist's shift from the client's explicit self-positioning as being concerned about the loss of her ability to help her boyfriend to the emotion of sadness implies a shift in focus from the otherrelated concern about the boyfriend to the client's emotional self. This combines with a shift of the object of the emotion, namely, from the loss of the ability to help to the loss of the relationship itself. This shift paves the way for the therapist's permission to allow for her sadness sufficiently in order to be able to cope with the separation from the boyfriend. The therapist's shift to the client's performative self is thus used as a cue to enhanced emotional self-exploration by the client, on which the therapist builds his recommendation.

The client aligns with the therapist's shift to her performative emotional self and affiliates with his statements. The shift in focus establishes the common ground between therapist 
and client about the client's emotional state that is needed as a basis for the intelligibility and acceptability of the therapist's recommendation.

\section{Summarizing Impressions From Client's Talk: Challenging the Authenticity of the Performance}

In extract 5 from an earlier session, the therapist seemingly gives just a summary of the client's prior talk, which, however, can be heard as challenge building on the impression that the client interactional performance conveys. The client had talked for the first $11 \mathrm{~min}$ about her current life situation (preparing university exams, leisure-time activities, boyfriend, and plans to move to another town). She stated that she did not suffer from seizures recently, but reported eating problems, which, however, she claimed to be under control of "her head" (01-06).

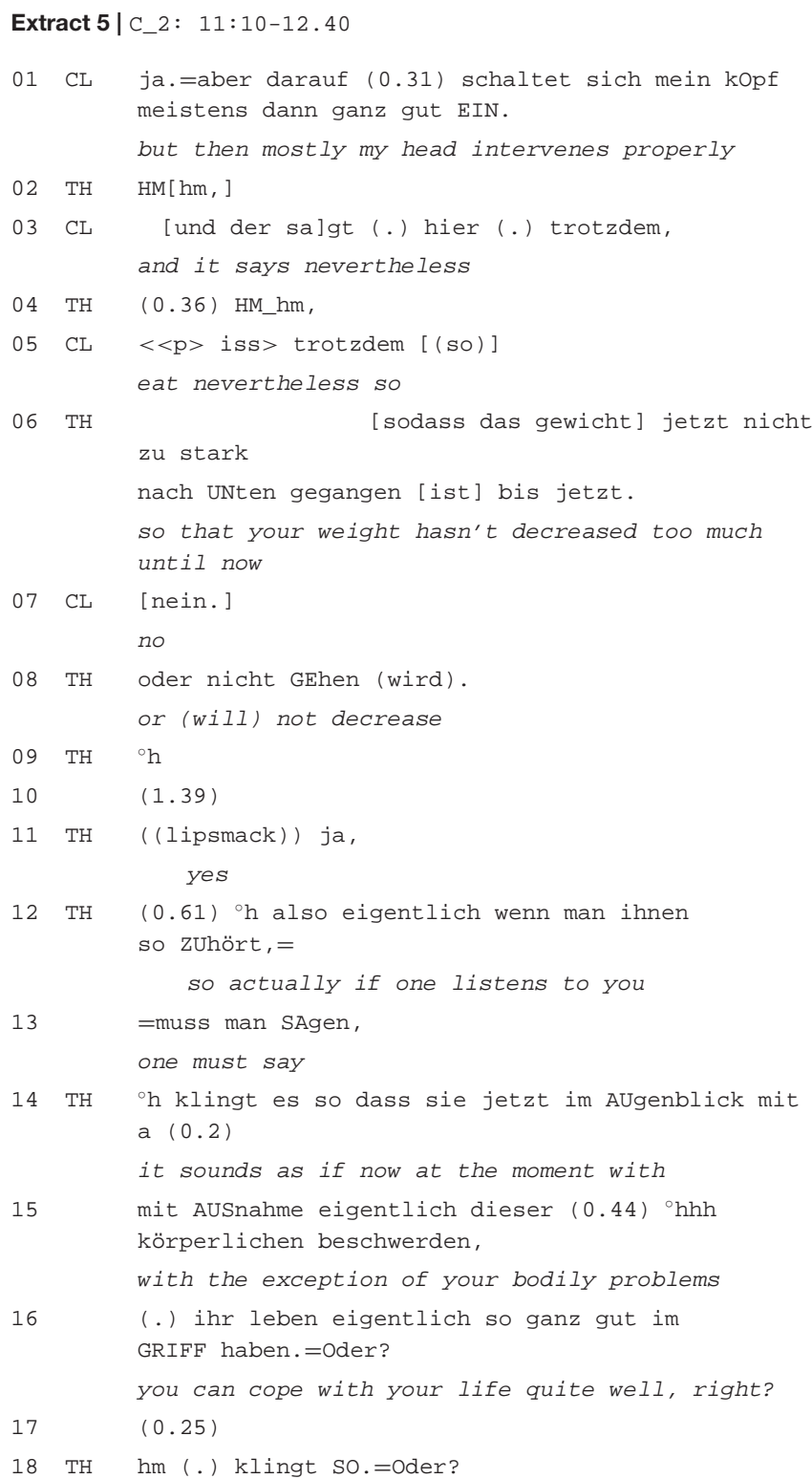

sounds like that right?

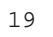

20
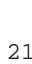

21

22

23

24

25

$40 \mathrm{~T}$

$41 \mathrm{CL} \quad(0.28)$ ah:m: und (0.98) wenn ich so EINS zwei mal über dinge

geSPROchen hab;

erm and when I like once or twice talked about things

$42 \quad(0.3)$

$43 \mathrm{CL}$ dass ich dann auch relativ neutRAL.

that I reported relatively neutral then as well

$44 \quad(1.04)$

$45 \mathrm{TH} \quad \mathrm{hm} \_[\mathrm{HM},]$

46 CL [DAR]stell:e;

\section{The Client's Story: Presentation of a Rational and Trouble-Free Self (Until 05)}

The client tells about various domains of her life, mostly smilingly. She does not mention major problems and presents 
herself as a well-organized and goal-oriented person by her account. Her health problems are only addressed in response to an inquiry by the therapist; yet, they are portrayed by the client as being under her control.

\section{The Therapist's Response: Challenging the Impression the Client Gives by Mirroring (06-20)}

The therapist completes and thereby confirms the client's story, stating that she manages to control her weight appropriately (06-08). He summarizes the impression created by the client's account with "you can cope with your life quite well" (16). This summary is framed by verbs of perception $(12,14$, 18) as how the client "sounds" when "listening" to her. In particular, the concluding repeat "klingt SO. = Oder?", "sounds like that, right?" (18) can be heard as a challenge, because again the perceptual impression that the client's story conveys, but not its truth, is highlighted. The tags oder? ("right," 16, 18; see König, 2020) and the following questions (19-20) explicitly ask the client to take a stance on this impression, thus implicitly calling, or at least allowing, for the client's self-repair.

\section{Ensuing Negotiation: Client Admits Insincerity}

With the ambiguous response token "jein" (a blend of yes and no), the client indexes that no straightforward answer is possible and projects a complex elaboration (Bücker, 2013). The client avows that she is able to give a favorable, unproblematic impression "to the outside" (28-32), thus letting infer that this does not correspond to how she actually feels. When saying that she "catches herself" (35) when "smiling away many things" (39), she adumbrates that this is a habitual way of presenting herself that she herself often is not aware of, but was only averted to by a former therapist (37).

\section{Self- and other-positioning in extract 5}

The client initially positions herself as a rational, goal-oriented person, who can cope with the (minor) troubles she faces. The therapist confirms this positioning, yet by stressing its perceptual nature and explicitly asking for the client's take on this impression, he implicitly leaves room for doubt and indexes the need for deeper elaboration concerning the validity of the client's self-positioning. The therapist does not explicitly other-position the client. In response, the client avows a lack of sincerity in her self-presentation, distinguishing a habitual facade of unproblematicity for others from the real self ${ }^{3}$, which, however, she does not elaborate on in the context of the extract.

\section{CONCLUSION}

In Western culture, there is a deep-rooted assumption that subjects have privileged access to their own self (Heritage, 2011; Gertler, 2020). This assumption is embodied in most interaction types in the preference not to question subjective experience and

\footnotetext{
${ }^{3}$ The client's distinction between a publicly displayed and a real self is reminiscent of Reich's psychoanalytic account of the "facade" (Reich, 1933) and Goffman's socio-psychological account of self-presentation (Goffman, 1959).
}

self-related statements, but instead to affiliate with them and show empathy. Yet, the rationale of almost every psychotherapy includes to cause psychological change by altering clients' selfperceptions, self-ascriptions, and understandings of motives and goals by the therapist's interventions. This includes questioning the client's epistemic authority on their own self, which is a sensitive move that has to be carefully considered each time anew.

One way to question the client's authority concerning their self is to shift from the client's focus on their autobiographical, told self of which they are conscious to their performative self, which they enact in the interaction with the therapist. This latter self usually is rather, in terms of Goffman (1959), "given off" than part of what the client intentionally conveys about their self. In psychoanalytic terms, addressing the performative self thus often means to address unconscious and sometimes conflictual aspects of the client's personality, feelings, and motives. Prior research on interpretations has shown that they regularly include ascribing emotions to the client that they have not explicitly addressed or even seemed to hide (e.g., Vehviläinen, 2003; Peräkylä, 2008; Voutilainen et al., 2010; Muntigl and Horvath, 2014). Our analyses show that shifts to the performative level of client's conduct therapists' interpretations can still address other facets of the client's self. In particular, they can concern motives for their interactional conduct that the client did not address in their talk, claims about how the client designs the current interaction with the therapist, a shift in causes or objects that are seen as causes for the client's emotions, and challenges of the authenticity of the client's self-positioning, again pointing to unavowed motives and emotions of the client. The shift to topicalizing such performative aspects of the client's conduct amounts to a severe face threat in at least two ways: epistemically, the client is treated as not being (fully) authoritative on their own self; morally, the adequacy of the client's behavior, their goals, and motives are put into question. Thus, psychotherapists are faced with the dilemma to get clients to conceive of their selves in new and often oppositive ways, but yet to respect the clients' face.

In the data, we could see that therapists deal with this dilemma by a particular design of the interpretations that address the performative self of the client as the therapist perceives it in situ. Therapists produce lengthy multi-unit turns that start with a display of understanding and empathy with the client that explicitly ratify the client's perspective. Only after this do they turn to a competing perspective that the client does not seem to be aware of, but that is treated as equally or even more important, ascribing behaviors, motives, and feelings that are different from the ones the client has addressed (extracts 25 ) or that serve as a motivational explanation (extract 1). This competing perspective is not just posited, but argumentatively backed with reference to the client's own prior talk (Weiste et al., 2015), to a common ground that has been built earlier in the psychotherapy, general world knowledge, and the therapist's own imaginations concerning the told episodes. Thus, the interpretation is not just delivered as a unilateral observation from a more authoritative, expert position, but therapists try to ground it intersubjectively in joint observation of the client's talk and behavior and their shared interactional history. Furthermore, the therapist's interpretation is introduced in a more or less 
tentative, hypothetical way (see Stukenbrock et al. submitted), which invites the client to self-explore further in the direction of the self-aspects that the interpretation points at. This observation corresponds to current conceptualizations of psychoanalytic interpretation (Heimann, 2016; Civitarese, 2020) that stress its intersubjective and relational aspects.

Yet, this complex and careful design of the therapist's shift to the client's performative self does not always cause clients to align with it, agree with the therapist's interpretation, and indulge in enhanced self-exploration (as in extracts 1, 4, and 5). They may resist (extract 3) or confirm only partially or in passing without entering into a more detailed exploration of the interpretive perspective that the therapist offers (extract 2). In addition, as extract 1 has shown, there may even be a deep misunderstanding between client and therapist in the sense that the client overtly agrees with the therapist, while misconstruing the therapist's action and assessment.

We found that the therapists' shift to the performative self involves focusing on the client's feelings and motives, but less on categorical psychological or moral identity claims (e.g., strength, rationality, honesty), which are focal in clients' stories. Thus, different facets of the self matter to different participants. While prior research on psychotherapy has shown that therapists' interpretations attend in particular to emotions that the client did not address, the positioning perspective adopted in this paper enlarges the picture of how therapists attend to latent psychological aspects. Psychodynamic therapists are more generally sensitive to the here-and-now performance of the client, which importantly includes their ways to conduct the interaction with the therapist, their bodily displays and motives that their discursive actions make available for the therapist. In this way, therapists attend to a larger notion of the client's self that transcends autobiographically based narrative representations in favor of the vision of a performative self that reveals itself in the ways it acts in situ.

Sequential analysis of the negotiations between client and therapist following the therapist's shift to the performative self show that such shifts promote the therapeutical agenda by inviting the client's self-exploration (cf. Peräkylä, 2010). Therapists do not necessarily expect clients to confirm straight away the interpretations that they tentatively offer about the client's self. Rather, they use them to elicit and deepen the client's self-exploration, which does not always have to follow closely

\section{REFERENCES}

Antaki, C. (2012). Affliative and disaffiliative candidate understandings. Discourse Stud. 14, 531-547. doi: 10.1177/1461445612454074

Bamberg, M. (1997). Positioning between structure and performance. J. Narrative Life Hist. 7, 335-342. doi: 10.1075/jnlh.7.42pos

Bamberg, M. (2011). Who am i? Narration and its contribution to self and identity. Theory Psychol. 21, 3-24. doi: 10.1177/0959354309 355852

Bamberg, M., and Georgakopoulou, A. (2008). Small stories as a new perspective in narrative and identity analysis. Text Talk 28, 377-396. doi: 10.1515/TEXT.2008.018 along the lines of what the interpretation has suggested. Rather, the interpretation can be treated by both parties as a starting point for exploring a better understanding of the client that is to be worked out collaboratively. However, if the client resists to this elicitation, therapists insist on their interpretation, often couching it in more definite and more saturated terms (Will, 2016), making it less tentative (as in extract 3). The shift in positioning levels thus seems to have a preparatory function for promoting the therapeutic agenda and for engendering therapeutic insights, which build immediately on what is intersubjectively observable in the client's multimodal conduct.

\section{DATA AVAILABILITY STATEMENT}

All datasets presented in this study are included in the article.

\section{ETHICS STATEMENT}

The studies involving human participants were reviewed and approved by Ethik-Kommission der Albert-Ludwigs-Universität Freiburg. The patients/participants provided their written informed consent to participate in this study. Written informed consent was obtained from the individual(s) for the publication of any potentially identifiable images or data included in this article.

\section{AUTHOR CONTRIBUTIONS}

All authors have conducted the analyses presented. AD has written the paper. CS was responsible for data collection. All authors contributed to the article and approved the submitted version.

\section{ACKNOWLEDGMENTS}

We thank Aleksandra Gubina for corpus documentation, transcription, and valuable comments to a prior version of this text. Prior versions of this work have been presented at the International Conference on Conversation Analysis and Psychotherapy ICCAP19 in Berlin and at the 4th meeting of the DFG-Netzwerk "Linguistik und Medizin," Mannheim. Article processing charges have been covered by the LeibnizInstitut für Deutsche Sprache and the Leibniz Open Access Publishing Fund.

Boothe, B. (2004). Der Client als Erzähler in der Psychotherapie. Gießen: Psychosozial-Verlag.

Boothe, B. (2010). Das Narrativ. Biografisches Erzählen im psychotherapeutischen Prozess. Stuttgart: Schattauer.

Bücker, J. (2013). Jein: Formen und Funktionen einer Dialogpartikel in Mündlichkeit und Schriftlichkeit. Z. Ger. Linguistik 41, 189-211. doi: 10.1515/zgl-2013-0012

Civitarese, G. (2020). Sag es "schräg": die Rolle der Deutung in der postbionschen Theorie des analytischen Feldes. Jahrb. Psychoanal. 80, 29-78.

Deppermann, A. (2013). (What) does "positioning" offer more than "membership categorization"? Evidence from a mock story. Narrative Inq. 23, 62-88. doi: 10.1075/ni.23.1.04dep 
Deppermann, A. (2015). "Positioning." in The Handbook of Narrative Analysis, eds A. De Fina, and A. Georgakopoulou (New York, NY: Wiley-Blackwell), 369-387. doi: 10.1002/9781118458204.ch19

Freud, A. (1937). The Ego and the Mechanisms of Defence. London: Hogarth Press and Institute of Psycho-Analysis.

Freud, S. (1924[1914]). "Further recommendations in the technique of psychoanalysis: recollection, repetition, and working-through," in Collected Papers, Vol. 2, ed S. Freud (London: Hogarth), 366-376.

Gertler, B. (2020). "Self-knowledge," in The Stanford Encyclopedia of Philosophy (Spring 2020 Edition), ed E. N. Zalta (Stanford University Library of Congress Catalog Data). Available online at: https://plato.stanford.edu/archives/spr2020/ entries/self-knowledge (accessed June 3, 2020).

Goffman, E. (1955). On face-work: an analysis of ritual elements in social interaction. Psychiatry 18, 213-231. doi: 10.1080/00332747.1955.11023008

Goffman, E. (1959). The Presentation of Self in Everyday Life. New York, NY: Anchor

Greenson, R. R. (1978). The Technique and Practice of Psychoanalysis. London: Hogarth.

Heimann, P. (2016). Gegenübertragung und andere Schriften zur Psychoanalyse. Stuttgart: Klett-Cotta.

Heritage, J. (2011). "Territories of knowledge, territories of experience: empathic moments in interaction," in The Morality of Knowledge in Conversation, eds T. Stivers, L. Mondada, and J. Steensig (Cambridge: Cambridge University Press), 159-183. doi: 10.1017/CBO9780511921674.008

Jayyusi, L. (1984). Categorization and the Moral Order. New York, NJ: Routledge.

König, K. (2020). "Prosodie und epistemic stance: Konstruktionen mit finalem oder," in Prosodie und Konstruktionsgrammatik, eds W. Imo, and J. Lanwer (Berlin: de Gruyter), 167-199. doi: 10.1515/978311063 7489-006

Kupetz, M. (2016). Empathie im Gespräch: Eine interaktionslinguistische Perspektive. Tübingen: Stauffenburg.

Levy, M. S. (1998). A helpful way to conceptualize and understand reenactments. J. Psychother. Pract. Res. 7, 227-235.

Lucius-Hoene, G., and Deppermann, A. (2004). Narrative Identität und Positionierung. Gesprächsforschung 5, 166-183. Available online at: http:// www.gespraechsforschung-online.de/heft2004/heft2004.html (accessed October 8, 2020).

Mondada, L. (2018). Multiple temporalities of language and body in interaction: challenges for transcribing multimodality. Res. Lang. Soc. Interact. 51, 85-106. doi: 10.1080/08351813.2018.1413878

Muntigl, P., and Horvath, A. O. (2014). "I can see some sadness in your eyes": when experiential therapists notice a client's affectual display. Res. Lang. Soc. Interact. 47, 89-108. doi: 10.1080/08351813.2014.900212

Neisser, U. (1988). Five kinds of self-knowledge. Philos. Psychol. 1, 35-59. doi: 10.1080/09515088808572924

Peräkylä, A. (2005). Patients' responses to interpretations: a dialogue between conversation analysis and psychoanalytic theory. Commun. Med. 2, 163-176. doi: 10.1515/come.2005.2.2.163

Peräkylä, A. (2008). "Conversation analysis and psychoanalysis: interpretation, affect and intersubjectivity, " in Conversation Analysis and Psychotherapy, eds A. Peräkylä, C. Antaki, S. Vehviläinen, and I. Leudar (Cambridge:
Cambridge University Press), 100-119. doi: 10.1017/CBO9780511490 002.007

Peräkylä, A. (2010). Shifting the perspective after the patient's response to an interpretation. Int. J. Psychoanal. 91, 1363-1384. doi: $10.1111 /$ j.1745-8315.2010.00323.x

Reich, W. (1933). Charakteranalyse: Technik und Grundlagen für Studierende und Praktizierende Analytiker. Wien: Manz. doi: 10.1097/00005053-193409000-00061

Schegloff, E. A. (1992). Repair after next turn: the last structurally provided defense of intersubjectivity in vonversation. Am. J. Sociol. 97, 1295-1345. doi: $10.1086 / 229903$

Schegloff, E. A. (2007). Sequence Organization in Interaction. Cambridge: Cambridge University Press. doi: 10.1017/CBO9780511791208

Selting, M., Auer, P., Barth-Weingarten, D., Bergmann, J., Bergmann, P., Birkner, K., et al. (2011). A system for transcribing talk-in-interaction: GAT 2. Translated into English and adapted by Elizabeth Couper-Kuhlen and Dagmar Barth-Weingarten. Gesprächsforschung 12, 1-51.

Streeck, U. (2004). Auf den ersten Blick. Psychotherapeutische Beziehungen unter dem Mikroskop. Stuttgart: Klett-Cotta.

Vehviläinen, S. (2003). Preparing and delivering interpretations in psychoanalytic interaction. Text 23, 573-606. doi: 10.1515/text.2003.022

Voutilainen, L., Peräkylä, A., and Ruusuvuori, J. (2010). Recognition and interpretation: responding to emotional experience in psychotherapy. Res. Lang. Soc. Interact. 43, 85-107. doi: 10.1080/08351810903474799

Weiste, E., Voutilainen, L., and Peräkylä, A. (2015). Epistemic asymmetries in psychotherapy interaction: therapists' practices for displaying access to clients' inner experiences. Sociol. Health Illn. 38, 645-661. doi: 10.1111/1467-9566.12384

Weiste, S., and Peräkylä, A. (2013). A comparative conversation analytic study of formulations in psychoanalysis and cognitive psychotherapy. Res. Lang. Soc. Interact. 46, 299-321. doi: 10.1080/08351813.2013.839093

Wilkinson, S., and Kitzinger, C. (2003). "Constructing identities: a feminist conversation analytic approach to positioning in action," in The Self and Others: Positioning Individuals and Groups in Personal, Political and Cultural Contexts, eds R. Harré, and F. M. Moghaddam (Westport, CT: Praeger), 157-180.

Will, H. (2016). Ungesättigte und gesättigte Deutungen. Psyche Z. Psychoanal. 70, 2-23. doi: 10.21706/ps-70-1-2

Zifonun, G., Hoffmann, L., and Strecker, B. (1997). Grammatik der deutschen Sprache, Vol. 3. Berlin: de Gryuter.

Conflict of Interest: The authors declare that the research was conducted in the absence of any commercial or financial relationships that could be construed as a potential conflict of interest.

Copyright (c) 2020 Deppermann, Scheidt and Stukenbrock. This is an open-access article distributed under the terms of the Creative Commons Attribution License (CC $B Y)$. The use, distribution or reproduction in other forums is permitted, provided the original author(s) and the copyright owner(s) are credited and that the original publication in this journal is cited, in accordance with accepted academic practice. No use, distribution or reproduction is permitted which does not comply with these terms. 


\section{APPENDIX}

Appendix A | Transcription Conventions GAT 2 (Selting et al., 2011).

\begin{tabular}{|c|c|}
\hline [ ] & overlap and simultaneous talk \\
\hline$=$ & immediate continuation with a new turn or segment, latching \\
\hline${ }^{\circ} \mathrm{h} / \mathrm{h}^{\circ}$ & in-/outbreaths of $\sim 0.2-0.5 \mathrm{~s}$ duration \\
\hline${ }^{\circ} \mathrm{hh} / \mathrm{hh}^{\circ}$ & in-/outbreaths of $\sim 0.5-0.8 \mathrm{~s}$ duration \\
\hline (.) & micro pause, estimated, up to $0.2 \mathrm{~s}$ duration \\
\hline$(0.5)$ & measured pause \\
\hline and_uh & cliticizations of units \\
\hline uh, uhm, etc. & hesitation markers, so-called "filled pauses" \\
\hline : & lengthening, by about $0.2-0.5 \mathrm{~s}$ \\
\hline$::$ & lengthening, by about $0.5-0.8 \mathrm{~s}$ \\
\hline ((laughs)) & description of laughter and crying \\
\hline$<<$ laughing $>>$ & comment on speech delivery with indication of scope \\
\hline SYLlable & focal accent \\
\hline sYllable & secondary accent \\
\hline !SYL!lable & extra strong accent \\
\hline$?$ & rising to high \\
\hline , & rising to mid \\
\hline- & level intonation \\
\hline ; & falling to mid \\
\hline & falling to low \\
\hline$<<\mathrm{p}>>$ & piano, soft \\
\hline$<<f>>$ & forte, loud \\
\hline$<<$ decr $>$ & decrescendo, becoming softer \\
\hline (may i) & assumed wording \\
\hline
\end{tabular}

Appendix B | Multimodal Transcription Conventions (Mondada, 2018).

** Gestures and descriptions of embodied actions are delimited between two identical symbols (one symbol per participant) and synchronized with correspondent stretches of talk.

* $--->\quad$ The action described continues across subsequent lines.

$--->^{*} \quad$ until the same symbol is reached.

-- $\quad$ Action-apex is reached and maintained. 